\title{
БОЖЕСТВЕННІ ЕНЕРГІЇ ТА БОГОСЛОВСЬКИЙ МЕТОД У ВЧЕННІ СВ. ГРИГОРІЯ ПАЛАМИ
}

Вчення святого Григорія Палами про енергії завжди викликало неоднозначну реакцію - як у своїх сучасників, так і в дослідників, які вивчали його та інтерпретували це вчення. Григорій Палама запропонував розрізнення між сутністю та енергіями в Бозі, аби богословськи осмислити та артикулювати містичний досвід монахів-ісихастів, що проявлявся зокрема у баченні надприродного нематеріального світла, яке вони називали Таворським світлом. Григорій Палама розробив це вчення не просто як теорію, яка випливала 3 його власних міркувань, а передусім як відповідь на нагальну потребу пояснити цей надприродний досвід тим людям, чия світоглядна перспектива не дозволяла їм зрозуміти сенс тих духовних практик, якими відзначилися ісихасти. Звідси бачимо, що досвід $є$ первинним щодо формування цієї теорії, яка слугує скоріше його поясненням, а отже, має виняткову цінність для розуміння, чим, власне кажучи, $є$ богопізнання, які його передумови та яким чином воно відбувається. Саме спілкування з Богом є центральним об'єктом зацікавлення Григорія Палами, і вся його тріадологія, сотеріологія, сакраментологія, теорія пізнання - все обертається навколо питання: як Бог виходить назустріч людині й дає себе пізнати, засмакувати Свого життя. Адже ключова проблема людського існування, центральна ціль людини і всього створіння - це осягнути якомога повнішу єдність з Богом.

Вже $є$ чимало досліджень, присвячених цьому аспекту вчення Григорія Палами. Православний світ знає майже безперервну традицію почитання св. Григорія Палами та поширення ідей та практик ісихазму, зокрема на теренах колишньої Київської Русі ${ }^{1}$. Попри те, наукове дослідження

" Mariia Hupalo STB - Assistant at Theology Department, Faculty of Philosophy and Theology, Ukrainian Catholic University (Lviv) [Марія Гупало - асистент кафедри богослов'я Філософсько-богословського факультету Українського Католицького Університету (Львів); e-mail: mhupalo@ucu.edu.ua.

${ }^{1}$ На українських теренах одним із основних центрів ісихастського руху була Києво-Печерська Лавра. Реформи Катерини II справили нищівний вплив на монастирське життя як в Україні, так і в цілій Російській імперії. Старець Паїсій Величковський (1722-1794), який у пошуках автентичного східнохристиянського монашого життя потрапив на Афон, найбільше спричинився до відродження ісихазму в Україні та поширення „старчества” в Росії. 
паламізму та феномену ісихазму навіть у православних Церквах було занедбане аж до XIX століття ${ }^{2}$. Західний науковий світ уперше ознайомився зі спадщиною св. Григорія Палами після століть забуття завдяки піонерській праці афонського монаха Василія Кривошеїна Аскетичне $і$ богословське вчення св. Григорія Палами (1938)³. Вагомий здобуток у вивченні богослов’я Григорія Палами належить Йоанові Меєндорфу, який написав авторитетну монографію Жизнь и труды святителя Григория Паламы. Введение в изучение. Певні напрацювання на цю тематику належать також російським дослідникам XIX ст. Ф. Успенському, П. Сирку. Особливу увагу заслуговує праця румунського священика Думітру Станілое ${ }^{4}$, який цитував в оригіналі невидані до того часу праці Палами, а також о. Кипріяна Керна ${ }^{5}$. Серед сучасних дослідників можна назвати Олів'є Клемана, митр. Калліста (Уера), Христоса Яннараса ${ }^{6}$. I, безперечно, визнаними знавцями спадщини Григорія Палами є Володимир Лосський ${ }^{7}$ та Георгій Флоровський ${ }^{8}$, які писали свої праці на дану тематику в 1940-50-х роках минулого століття, осмислюючи спадщину Палами в рамках неопатристичного синтезу.

У цій статті спробуємо розглянути, яким чином Григорій обгрунтовує можливість містичного досвіду за посередництвом божественних енер-

Він першим почав перекладати твори видатних подвижників та містиків й укладати збірку святоотцівських текстів, присвячених практиці Ісусової молитви, яка згодом отримала назву Добротолюбіс (Філокалія). Насправді Філокалія, яку видали Макарій Коринтський та Никодим Святогорець у 1782 році, частково базувалася на тих текстах, які вже попередньо зібрав Паїсій Величковський, див. К. Ware, The Inner Unity of the Philokalia and its Influence in East and West, Athens 2004. Пор. C.G. et V. Conticello, La théologie byzantine et sa tradition, vol. 2, Turnhout 2002, 999-1021. Також саме завдяки Паїсію Величковському стала можлива поява таких осередків, як Оптинська пустинь, Саров та інші, а також поширення практики Ісусової молитви не лише в монастирях, але й серед мирян, про що свідчить твір „Щирі розповіді прочанина своєму духовному отцеві”. За свідченням Пентковського, його авторами були не лише маловідомі монахи, але й такі велетні духа, як Теофан Затворник. Див. А.М. Пентковский, $O m$ „Искателя непрестанной молитвы” до „Откровенных рассказов странника”: (К вопросу об истории текста), „Символ” 27 (1992) 137-166. Детальніше про долю культу св. Григорія Палами в УГКЦ та його пізнішої легітимації див. В. Жуковський, Святий Григорій Палама і його легітимізація в УГКЦ, „Наукові записки УКУ. Серія «Богослов’я»” 1 (2009) 145-159.

2 Пор. D. Reid, Energies of the Spirit. Trinitarian Models in Eastern Orthodox and Western Theology, Atlanta 1997, 20.

${ }^{3}$ V. Krivosheine, The Ascetic and Theological Teaching of Gregory Palamas, ,Eastern Church Review" 3 (1938) 26-33, 71-84, 138-156 та 193-214.

${ }^{4}$ D. Stăniloae, Viața şi Învăţătura Sfântului Grigorie Palama, Bucureşti 1993.

${ }^{5}$ K. Керн, Антропология св. Григория Паламы, Москва 1996.

${ }^{6} \mathrm{C}$. Yannaras, The Distinction between Essence and Energies and Its Importance for Theology, VTQ 19 (1975) 232-245.

${ }^{7}$ В. Лосский, Очерк мистического богословия Восточной Церкви. Догматическое богословие, Москва 1991.

${ }^{8}$ Г. Флоровский, Святой Григорий Палама и традииия Отиов, пер. Н. Холмогоровой, „Альфа и Омега” 9/10 (1996) 107-116. 
гій. У Tріадах на захист святих ісихастів Палама не тільки стверджує існування розрізнення між сутністю та енергіями, але й обгрунтовує засади богопізнання через ці енергії, описуючи їх як іпостасний стосунок між Богом і людиною, в якому Бог не тільки відкривається людині, але й підносить їі, усиновляє й робить подібною до Себе за благодаттю. Палама різко висловлюється проти розходження знання із практикою, для нього справжнє знання - лише те, яке отримане в єднанні, понадрозумне, невимовне, надприродне. Він визнає лише те знання, яке приходить через особистий досвід спілкування з Богом, містик $є$ найбільшим авторитетом, натомість пізнання через відокремлення ума від об'єкта спостережень він вважає нелегітимним у сфері богопізнання. Але цей досвід неможливий без того, щоб Бог Сам Себе об'явив, а це можливо лише в тому випадку, якщо Його енергії, або само-маніфестації, є нетварними. Тому наша стаття розпочинається з розгляду проблематики самих енергій та їхньої природи, пізніше переходить до того, яким чином вони виступають середниками містичного досвіду та єднання з Богом. Врешті, в кінці спробуємо заторкнути питання іпостасності божественних енергій.

1. Енергія як невід'смна маніфестація Бога ad extra. Вихідним пунктом паламітського богослов'я було питання, яким чином людина може пізнати Бога і досвідчити Його присутність, якщо Бог у своїй сутності є абсолютно трансцендентним. Його ціллю було пояснити, яким чином досвід божественного світла, який переживали ісихасти, був можливим і легітимним. Отже, необхідно було підкреслити одночасну трансцендентність та іманентність Бога, Його одночасну пізнаваність і непізнаваність, цілісність та відкритість назовні, або ж, більш сучасною мовою, Трійцю іманентну та ікономічну. Для цього Григорій Палама увів розрізнення між сутністю та енергією. Иого опонент Варлаам Калабрійський постулював ідею богопізнання як виключно філософської вправи та вдосконалення ума, сотвореного на Божий образ, таким чином звівши християнство до діяльності інтелектуала. Він стверджував, що безпосередній контакт з Богом $є$ неможливий, адже Бог $є$ трансцендентним. Натомість Палама підкреслював, що спілкування з Богом є доступним кожній людині, незалежно від ії освіти й здібностей, інакше це суперечить самій суті християнства. Проте він прагнув зберегти в Бозі полярність між тим, що доступне і що недоступне до участі. Тому він провів розрізнення між сутністю, іпостасями та несотвореними енергіями в Бозі, що не сподобалось його опонентам, оскільки вони вважали Бога абсолютно простим. Це розрізнення було необхідним для того, щоб показати, що стан обоження, що набувається людиною через співдію божественній несотвореній благодаті, не є ефемерним, він справді можливий не лише колись в есхатоні, але й вже тут, на землі. На думку Григорія Палами, 
якщо розуміти Бога лише як сутність, а енергії вважати сотвореними, то виявиться, що немає жодного посередника, який би подолав прірву між сотвореним і несотвореним і спроби Бога вийти назустріч людині незмінно розбивались би об неї.

Це розрізнення далеко не нове. Термін був введений у вжиток вже Арістотелем, був широко вживаний у неоплатонізмі ${ }^{9}$. У філософії Прокла зустрічаємо градацію між причиною, силою або енергією

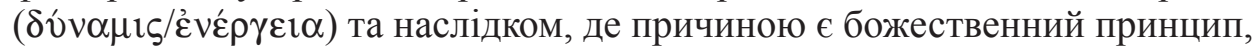
а наслідком - певне суще, чи то група сущих. Енергія випливає 3 причини і ділиться ії життям із наслідком, але енергія є за статусом нижчим буттям, ніж ії джерело. У свою чергу наслідок (грубо кажучи, створіння) $\epsilon$ нижчим за енергію, в якій бере участь ${ }^{10}$. Можна прослідкувати значний вплив Прокла на те, яким чином Псевдо-Діонісій Ареопагіт будує свою філософсько-богословську систему світу, а опосередковано - і на Григорія Паламу. Знаковим є використання для божественного єства терміну „понадсутність”, яку Діонісій Ареопагіт запозичує у Прокла, а Григорій Палама у свою чергу - у Діонісія. Під час тріадологічних суперечок Атанасій Олександрійський на противагу Арію ствердив, що енергія, тобто дія назовні, належить не іпостасі Бога-Отця, а всій Трійці, тобто це атрибут божественної сутності. Адже енергія, завдяки якій Бог творить світ та спілкується з ним, створює між Богом як суб'єктом та світом як його наслідком стосунок інакшості, відмінності природ. Тому між Отцем i Сином не може бути енергії, бо Син єдиносущний Отцеві ${ }^{11}$. Каппадокійці розвинули цю думку в полеміці з Свномієм, коли вперше на розгляд богословів виразно постало питання меж пізнання Бога людиною. Заперечуючи можливість пізнання Бога в Його сутності через термін

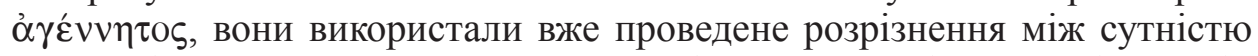
та енергіями, щоб ствердити, що Бог є пізнаваним остільки, оскільки Він себе об' являє нам. Григорій Нісський та Григорій Богослов використовують образ „плечей Бога” для пояснення, чим є божественні енергії. Трактуючи текст Вих 33, 19-23, Григорій Назіанзин використовує контраст „спина” - „лице”, щоб показати, що Бог у своїй непорушній природі відомий лише самому собі, а пізнаваною є лише та Його природа, що врешті спускається до нас і виражається у славі, коли Бог управляє своїми творіннями $^{12}$. Це розрізнення не між Богом і творіннями, а між тим, як Бог знає Себе і як ми Його знаємо.

\footnotetext{
${ }^{9}$ Див. D. Bradshaw, Aristotle East and West: Metaphysics and the Division of Christendom, New York 2004, 1-96.

${ }^{10}$ Пop. Proclus, Institutio theologia 56-57, ed. E.R. Dodds: Proclus, The Elements of Theology, Oxford 1933, 54.

11 Пор. Athanasius Alexandrinus, Epistula 2 ad Serapionem I 31, PG 26, 600C - 601A; I 19, PG 26, 573B - 576D.

${ }^{12}$ Пop. Gregorius Nazianzenus, Oratio 28, 3, éd. P. Gallay, SCh 250, Paris 1978, 104-107.
} 
Корпус Ареопагітиків значною мірою вплинув на епістемологію Па-

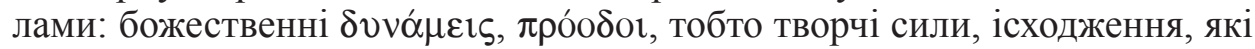
$\epsilon$ причинами існування всіх речей, є також само-об'явленнями Бога до нас $^{13}$. Цілий світ, згідно Псевдо-Діонісія, $є$ теофанією, вираженням Божої любові та турботи про своє створіння. У своєму творі Про Божественні імена Псевдо-Діонісій аналізує проблему, як цілком трансцендентний, понадсутнісний Бог може бути пізнаваним і доступним до участі, а також яким чином божественна сутність наділяється в Писанні різноманітними іменами. Він описує Бога як неподільну Одиницю, чиєю силою ми єднаємося в богоподібну монаду, а наші розрізнення трансцендентно

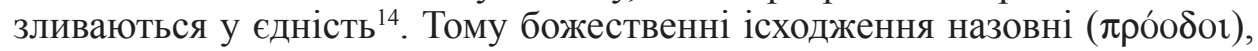

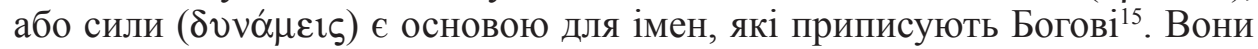
не лише виражають те, яким чином Бог виявляється назовні, але й Бога у Його простоті. Бог як Основа і Причина всього є анонімним, перевищує iмена ${ }^{16}$. Сотворений світ як результат стає символом, образом, у якому бачимо його причину, яка все ж залишається відносно нього трансцендентною ${ }^{17}$. Всі імена, що пасують Богові, завжди описуються Писаннями як такі, що стосуються не якоїсь частини, а всієї божественності у всій іiі цілісності, тому вони водночас відображають Бога і $є$ Богом, однак у той спосіб, у який людина може Його сприйняти ${ }^{18}$. Крім того, Діонісій роз-

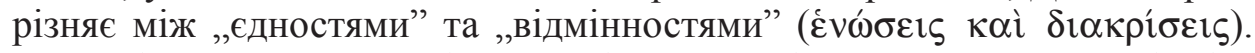
Єдності - це „понадсутнісна сутність”, повністю недоступна, а відмінності - це божественні маніфестації, ісходження, сили, в яких бере участь творіння і через які Бог пізнається в творіннях ${ }^{19}$.

Подальшого розвитку енергійне богослов'я зазнало під час суперечки між Максимом Ісповідником та монотелетами, в рамках якої Максим ще раз ствердив взаємозв'язок між природою та енергією, доводячи факт існування двох воль і двох дій у Христі - божественної та людської. Максим Ісповідник підкреслював нерозривність сутності та енергії, чи діяль-

${ }^{13}$ Докладніше про рецепцію і трансформацію Діонісія Григорієм Паламою можна знайти у статті A. Louth, Reception of Dionysius in the Byzantine world: Maximus to Palamas, „Modern Theology" 24 (2008) 585- 599.

${ }^{14}$ Mop. Dionysius Areopagita, De divinis nominibus 1, 4, PG 3, 589D.

${ }^{15}$ Пop. ibidem.

${ }^{16}$ Пop. ibidem 1, 7, PG 3, 596C-D.

${ }^{17}$ Пop. ibidem 2, 8, PG 3, 645C.

${ }^{18}$ Пор. ibidem 1, 8, PG 3, 597В. Володимир Лоський вважає, що розрізнення між перебуванням Бога у Собі та ісходженнями, яке окреслив Діонісій Ареопагіт, було першим чітким розрізненням між сутністю Бога та Його енергіями, див. А. Papanikolaou, Being with God: Trinity, Apophaticism, and Divine-Human Communion, Notre Dame 2006, 15.

${ }^{19}$ Пор. Dionysius Areopagita, De divinis nominibus 2, 4, PG 3, 640D - 641A: „Божественною єдністю сокровенні неісходні понадперебування понадневимовної й понаднепізнаваної постійності, розділеннями же - найблагіші ісходження Бога назовні та Його роз'яснення”, переклад мій. 
ності, як ії природної само-маніфестації, без якої будь-яка природа була б ілюзорною і непізнаваною ${ }^{20}$. Те ж саме говорить і Григорій Палама, коли пояснює, що сутнісне світло, як він інколи називає енергію, невіддільне від сутності: „навіть якщо ми назвемо цю енергію невіддільною від єдиної сутності, все одно Божа понадсутність не стане складеною, бо тоді взагалі не було б ніякої простої сутності, оскільки природної сутності без енергії не знайти жодної”21.

Таким чином Григорій Палама виступає продовжувачем православної доктрини про обоження, ядром якої є вчення про несотворені енергії. Розрізнення між сутністю та енергіями, або діями, закорінене у східнохристиянській традиції, а Григорій Палама лише поглибив його, наголошуючи на тому, що кожна енергія - це сам Бог у дії ${ }^{22}$. Григорій Палама, слідуючи за Каппадокійцями та іншими грецькими Отцями, творить „мета-онтологію”, проводячи розрізнення між сутністю, енергіями та іпостасями $^{23}$. Якби не було розрізнення між сутністю та енергіями, тобто між творенням та породженням/ісходженням, яке $є$ причиною існування іпостасей, то сотворена природа нічим не відрізнялась би від несотвореної і мала б буття, тотожне до буття Сина і Духа ${ }^{24}$ (це означає пантеїзм). Тому необхідно чітко розділити поміж функціями природи і функціями енергії: якщо першій властиво породжувати іпостасі, єдиносущні одна одній, то енергія відповідає за приведення до існування онтологічно іншого буття. Тому плутанина між цими функціями може призвести до фатальних наслідків для нашого розуміння Бога: ми або виключимо з Нього троїчність, або зробимо сотворені речі учасниками Пресвятої Тройці, зробимо Бога багатоіпостасним. Саме в цьому він часто звинувачує своїх опонентів, які намагалися редукувати Бога до одної лише сутності. Лише фундаментальне розрізнення енергії від сутності та стосунків між іпостасями в ній може показати, яким чином вірний у сакраментальній єдності з Христом

${ }^{20}$ Пор. Maximus Confessor, Opuscula theologica et polemica ad Marinum, PG 91, 201A-B, переклад мій: „Неможливо знати божественну чи людську природу, навіть знати, що вона існує

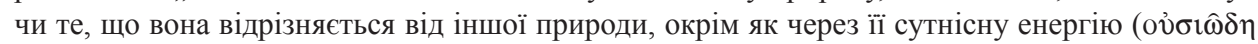

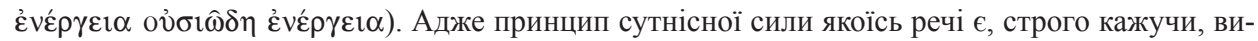
значенням цієї речі - якщо зникає ця сила, суб'єкт її зникає разом із нею”.

${ }^{21}$ Пop. Gregorius Palamas, Pro sanctis hesychastis III 1, 24, ed. J. Meyendorff: Grégoire Palamas, Défense des saints hésychastes, vol. 2, Spicilegium Sacrum Lovaniense 31, Louvain 1959, 603.

${ }^{22}$ Пop. D. Staniloae, The Experience of God: Orthodox Dogmatic Theology, vol. 1: Revelation and Knowledge of the Triune God, transl. I. Ionita - R. Barringer, Brookline 1998, 125; V. Lossky, In the Image and Likeness of God, transl. J.H. Ericson - T.E. Bird, New York 1974, 54.

${ }^{23}$ Пор. N. Tănase, „Crucifixion” of the Logic. Palamite Theology of the Uncreaded Divine Energies as Fundament of an Ontological Epistemology, „International Journal of Orthodox Theology" 6 (2015) nr 4, 73.

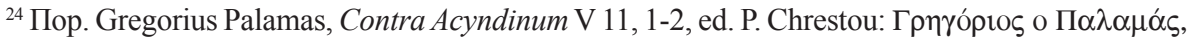

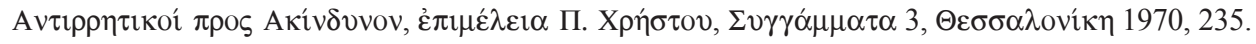
Див. L.C. Contos, The Essence-Energies Structure of St Gregory Palamas with a Brief Examination of Its Patristic Foundation, GOTR 12 (1967) 286. 
не стає ще одною іпостассю Божою. За умови такого розрізнення справді Боже сходження до людини є Його суверенним актом волі, так само, як і обоження людини ${ }^{25}$.

Григорій у згоді з усією християнською традицією стверджує віддаленість божественної сутності від сотвореної реальності, ії̈ абсолютної неподібності на будь-що з того, що мало початок. До божественної сутності неможливо застосувати жодні земні категорії, адже Бог, будучи Творцем, безмежно перевершує свої твори. Але якщо в Бозі є лише сутність, яка ніяк не комунікує із зовнішнім світом і до якої ніяк не можна бути причетним, постає питання: як узагалі Бог може бути пізнаваним? Чи можна тоді взагалі будь-що говорити про нього? Саме кенотичність буття Бога у Його спілкуванні з нами спонукало Григорія Паламу якось назвати цей активний, діяльнісний аспект божества, який слугує Його само-об'явленням людині, певною властивістю, яка $з$ одного боку характеризує Його, а з іншого залишається певною мірою нижчою за саму сутність ${ }^{26}$. Цю здатність Григорій називає благодаттю ( $\left.\chi \alpha \dot{\rho} \rho \varsigma\right)$, силою

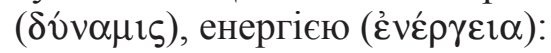

„Всі три [іпостасі] поділяють не лише трансцендентну сутність - яка водночас і безіменна, невиражальна, і несопричасна, оскільки вона є понад усі імена, вираження та участь - але також божественна благодать, сила, енергія, випромінення, царство і нетління, завдяки якому Бог через ласку входить у сопричастя і єдність із святими ангелами та угодниками"27.

Діяльність божественної сутності є безпочатковою і позачасовою. Григорій Палама навіть висловлюється в стилі I Нікейського Собору: „не було часу, коли не було чи чесноти, чи святості, чи безсмертя"28. Доводячи Варлаамові несотвореність божественних енергій, він підходить до опису енергій як божественних атрибутів, що безсумнівно співвічні Йому, однак ïx, попри очевидний нерозривний зв'язок із сутністю, не можна ототож-

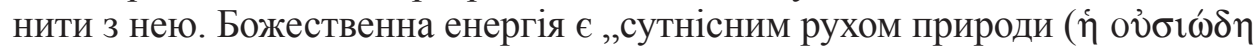

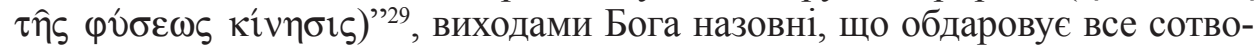
ріння життям, сутністю, а також обожує та дає мудрість. Хоч Палама називає ці божественні вияви благодаттю Божою, вони не є Божим даром людині, не річчю, а безпосереднім виявом самого живого Бога, особиста

\footnotetext{
${ }^{25}$ Пop. Gregorius Palamas, Pro sanctis hesychastis I 3, 10, ed. J. Meyendorff: Grégoire Palamas, Défense des saints hésychastes, vol. 1, Spicilegium Sacrum Lovaniense 30, Louvain 1959, 129.

${ }^{26}$ Пор. ibidem III 1, 23, ed. Meyendorff, vol. 2, с. 601, переклад мій: „Сили самі є сутнісними, але понадсутнісне i, більше того, «понадсутнісне-в-собі» цілісно і сукупно містить у собі ці сили. Отож, це обожуюче світло є сутнісним, однак само не є сутністю Бога". Див. Contos, The Essence-Energies Structure of St Gregory Palamas, p. 294.

${ }^{27} \mathrm{~K}$. Ware, God Hidden and Revealed: The Apophatic Way and the Essence-Energies Distinction, „Eastern Churches Review” 7 (1975) 130-131, переклад мій.

${ }^{28}$ Gregorius Palamas, Pro sanctis hesychastis III 2, 7, ed. Meyendorff, vol. 2, c. 655, переклад мій.

${ }^{29}$ Idem, Capita physica, theologica, moralia et practica 143, PG 150, 1220D.
} 
зустріч між створінням і Творцем. Вона $є$ „надлишковим виходженням єдиної природи", Божеством, яке себе звіщає тварному буттю ${ }^{30}$.

Слідом за Псевдо-Діонісієм Григорій Палама говорить про божественну сутність та нетварні енергії у термінах ісходження-повернення, розрізнення-єднання, таким чином підкреслюючи їхню роль у спілкуванні між багатоманітним сотвореним світом і Богом, який у своїй суті $\epsilon$ простим, але в різний спосіб об'являється людині: „Сднання володіють над [божественними] розрізненнями і переважають [над ними], не знищуючи їх при цьому і не маючи в них перепони до будь-чого" ${ }^{31}$. В. Лоський роз'яснює: „єднання” - це таємні перебування, які ніяк себе не проявляють, понадсутнісна природа, в якій Бог перебуває немовби в абсолютно-

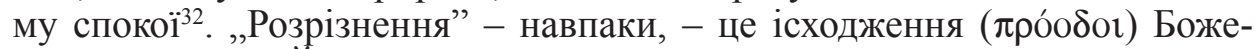

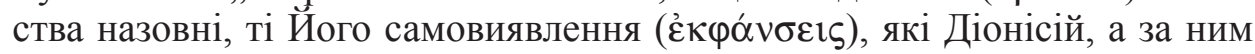

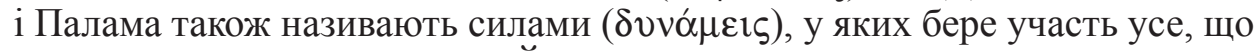
існує, даючи пізнання Бога у Його творінні. Саме ця антиномія єдностей і розрізнень дозволяє, на його думку, говорити про позитивне і негативне богослов'я, які так чітко розмежовуються в Діонісія. Божественні імена відповідають енергіям, через які Бог об'являється як той, кому ці якості належать, і через них Він спілкується із сотвореним світом, залишаючись неприступним у Своїй простоті. Таким чином, поділяючись, Він не розриває Своєї простоти ${ }^{33}$.

Через свої несотворені енергії Бог особисто уприсутнюється всюди. Його світло пронизує створіння, і водночас Бог є незмірно понад цим творінням $^{34}$. Цілий світ є великою неопалимою купиною, проникнутою чудесними й невимовними божественними енергіями ${ }^{35}$ Палама говорить:

„лише завдяки Його енергіям можна пізнати, що Бог існує. Отже, той, хто відкидає божественні енергії, обов'язково перебуває в невіданні присутності Божої'з6.

Божественні енергії є самим Богом, який сходить до нас особисто та відкриває Себе до зустрічі з нами. Розрізнення між сутністю та енергіями не $\epsilon$ витвором людського мислення (к $\alpha \tau^{\prime} \varepsilon \dot{\varepsilon} \tau^{\prime}(v o t \alpha v)$, а закорінене в саме буття Бога ${ }^{37}$, таким чином виражаючи Його повсякчасну готовність обожувати нас і притягувати до Себе. Незважаючи на те, що між сутністю

\footnotetext{
${ }^{30}$ К. Уер, Православна Церква, пер. Н. Рогачевської, Київ 2009, 74-75.

${ }^{31}$ Gregorius Palamas, Capita physica, theologica, moralia et practica 81, PG 150, 1177D, переклад мій.

${ }^{32}$ Пор. Лосский, Очерк мистического богословия Восточной Церкви, с. 56.

${ }^{33}$ Пop. ibidem, c. 57

${ }^{34}$ Пop. Gregorius Palamas, Pro sanctis hesychastis III 2, 7, ed. Meyendorff, vol. 2, c. 615.

${ }^{35}$ Пop. idem, Capita physica, theologica, moralia et practica 78, PG 150, 1176C.

${ }^{36}$ Ibidem 141, PG 150, 1220A, переклад мій.

${ }^{37}$ Григорій Палама говорить про реальне розрізнення (pragmatik $3 / 4$ difkrisij) між сутністю та енергією в Бозі.
} 
та енергіями є реальне розрізнення, не слід розуміти його як distinctio realis у латинському богослов”і, оскільки вона передбачає їх відмінність одне від одного за природою ${ }^{38}$. Натомість згідно богослов'я Палами божественна енергія мусить бути несотвореною, щоб обоження та реальна присутність Бога у світі була можлива. Сотворена благодать нездатна піднести людину до Бога, нездатна бути середником для трансценденції понад сотворену природу. Якщо людина споглядає сотворені енергії та сотворене Таворське світло, тоді це світло - не більше, як примара, яка не має жодного стосунку до Бога. Але Григорій Палама захищав не просто здатність Бога пізнати, але й з'єднатися із Ним у спосіб онтологічний, тобто ввійти у спілкування, стати учасником Божого життя, набути якостей, які за природою належать Богові, залишаючись при цьому сотвореною особою:

„Адже божественний Максим називав останнє не тільки воіпостасним, але й неродженим; не тільки нетварним, але й необмеженим і понадчасовим, так що ті, хто брав у ньому участь, в ньому стають нетварними, безначальними і безмежними, хоча із природи своєї виникли 3 нічого" 39 .

Палама описує це єднання в категоріях участі, виділяючи в Бозі той вимір, який доступний до участі, та той, який недоступний. Хоч він тут використовує мову неоплатонізму, божественне буття Палама трактує зовсім відмінно від неоплатоніків. Містицизм неоплатоніків - безособовий, чисто інтелектуальний рух, у ньому не просто відсутній діалог між Богом і творінням - Єдине не хоче промовляти до тих, які його взивають $^{40}$. Натомість Григорій Палама говорить, що це єднання не обмежується сферою ума, а охоплює цілу особу ${ }^{41}$. І якщо неоплатоніки розуміли участь як злиття з божественним на рівні сутності та відновлення первісної єдності всього буття, то наш автор розуміє іiі як особову участь, тобто стосунок між людською особою та Трійцею через обмін енергіями, і саме в цьому обміні енергіями Бог являється людині. Коли маємо це на увазі, краще розуміємо, чому божественна сутність є від-

${ }^{38}$ Пор. S. Tanev, ENEPГЕIA vs ГОФIA: The Contribution of Fr. Georges Florovsky to the Rediscovery of the Orthodox Teaching on the Distinction between the Divine Essence and Energies, „International Journal of Orthodox Theology” 2 (2011) nr 1, 18.

${ }^{39}$ Gregorius Palamas, Pro sanctis hesychastis II 3, 31, ed. Meyendorff, vol. 2, c. 443, переклад мій.

${ }^{40}$ Пор. С. Хоружий, Общение и созецание, исихазм и неоллатонизм: к взаимосвязи проблем, у: Общение-Соттипіо-Коіпопіа: истоки, пути осмысления и воплощения. Успенские чтения, Киев 2015, 139, А. Louth, The Origins of Christian Mystical Tradition: from Plato to Denys, New York 2007, 42.

${ }^{41}$ Ісихасти говорили про те, що осяяння нетварним світлом відбувається глибоко всередині людської особи, у її найсокровеннішому єстві, тобто серці. Вони розуміли серце у той спосіб, що Псевдо-Макарій - не як частину чи орган душі, а як центр життя людини. Пор. Т. Шпідлік, Духовність християнського Сходу, пер. $з$ італ. Мар'яна Прокопович, Львів 1999, 95-98. 
окремленою, закритою для нас. Палама каже, що вона безмежно перевищує власні само-маніфестації, що між Богом як діячем та енергіями як діями присутній стосунок причиновості, хоч енергії й співвічні Йому42. Попри те, що енергія правдиво показує нам Бога і дає істинне знання про Нього, все одно ця діяльність назовні, цей самовияв лише частково показує внутрішнє, приховане життя Бога, яке належить тільки Йому. Крім того, спілкування не може відбуватися на рівні сутності. На рівні природи можливий тільки стосунок єдиносущності або відмінності, природа статична, адже якби вона була мінливою, рухливою, то жодне буття не було б саме собою. Спілкування передбачає наявність іпостасі, яка здатна входити в спільність з іншими іпостасями, і характер пізнання, який походить із цієї спільності, відрізняється від того, який прагне об'єктифікувати того, кого хоче пізнати, прагне бути немовби „ззовні” нього. Бог як абсолютний Інший не надається до такої операції над собою, тому те, як Він постає перед нами, є єдиним джерелом нашого знання про Нього. Але навіть ця Божа слава, яка до нас сходить, настільки перевершує нас, що те, що ми здатні засвоїти, виявляється лише нікчемною часткою божественних маніфестацій.

2. Богопізнання через енергії та богословський метод. Динамізм божественної сутності та несотворених енергій є напругою між тим у Бозі, що є доступним для участі й тим, що недоступне, тобто те, що відкривається нам у досвіді, а що завжди залишається прихованим як для розумового пізнання, так і для досвіду. Вчення про енергії слугує поясненням Божої особової, екзистенційної присутності у нашому тілесному світі, всупереч платонівському дуалізму, який проводить чіткий вододіл між Богом як абсолютним і трансцендентним духом, цілковито іншим від світу та його матеріальної, приземленої, зосередженої в собі реальності, а також тенденціям західного теїзму гостро відокремлювати божественне і сотворене ${ }^{43}$.

„Адже ж усі ці начала є ніщо інше, як логоси і зразки для всього, що існує, і тому, хоч у них і беруть участь, вони перевершують суще як такі, що перебувають і передіснують в умі Творця, з якого все виникло. Чому ж їм не бути між несопричасним та учасниками? [...] оскільки існує те, що бере участь у Бозі, а понадсутнісної сутності Бога неможливо нікому причаститися, значить, існує між несопричасною сутністю й учасника-

${ }^{42}$ Пop. Gregorius Palamas, Pro sanctis hesychastis III 1, 9, ed. Meyendorff, vol. 2, c. 603.

${ }^{43}$ Пop. J. Cheng, The Distinction between God's Essence and Energy: Gregory Palamas' Idea of Ultimate Reality and Meaning, „Ultimate Reality and Meaning: Interdisciplinary Studies in Philosophy of Understanding" 21 (1998) 101; пор. Lossky, In the Image and the Likeness of God, c. 63. Розуміння Бога в схоластичному богослов'ї передовсім як вічної сутності, що не ініціює безпосередній контакт із людиною суперечило цим спробам паламізму показати, яким чином Бог може відкривати себе людині як особове буття в екзистенційному вимірі, у спілкуванні. 
ми те, через що вони беруть участь у Бозі. А якщо ти усуваєш те, що між несопричасним та учасниками - який збиток! - ти відриваєш нас від Бога, прибравши середню ланку, поклавши безмежну і нездоланну прірву між цією Основою та творенням й існуванням сотвореного буття. Видно, доведеться нам шукати іншого Бога [...] у якому якимось чином можна брати участь" $"$.

Процес богопізнання через енергії відрізняється від епістемологічного підходу Варлаама Калабрійського, який відображає схоластичний підхід до богословлення, густо забарвлений арістотелівським методом. Перш за все тим, що раціональне пізнання, яке ставив на перший план Варлаам, є лише символічним, зовнішнім ('ఓ $\xi \omega \theta \varepsilon v)$ відносно особи, відірваним від іiі особового буття предметом дослідження (саме такий підхід характеризує наукове пізнання), натомість світло божественних енергій просвічує наше духовне око й інтерналізується, ,змішуючись”

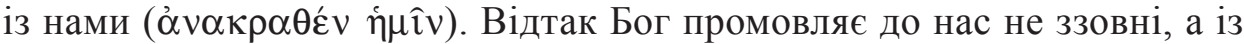
самого нашого нутра (ย้v $\delta \omega \theta \varepsilon v)^{45}$. Богопізнання, таким чином, не $\epsilon$ діяльністю виключно людського розуму, а охоплює всю істоту людини. Григорій Палама підкреслює антиномічність буття Бога, яке не вписується а арістотелівську логіку, адже попри присутність у Бозі енергій, які є нижчими за саму сутність, Бог ані не применшується, ані не стає складеним. Бог об’являє себе одночасно як сопричасний і несопричасний, пізнаваний і непізнаваний, як понад-сутність та як наближений до нас. Таке розуміння божества не дає можливість поставити його в рамки раціональної верифікації, базованої на силлогістичному методі арістотелівської логіки ${ }^{46}$, натомість відкриває іншу перспективу, яку можемо осягнути, лише покладаючись на власний містичний досвід або на досвід Бога тих, хто його справді зазнав. Правдиве знання Бога не може бути наслідком абстрактних розумувань, а лише наслідком живого стосунку з Богом. У цьому контексті Палама виділяє три групи людей, які прагнуть цього знання: містиків; тих, хто ще не досвідчив цього стану, але прислухаються до перших; тих, хто не досвідчив, але нікого не слухає і має власну думку ${ }^{47}$. Таким чином, для Палами саме містичний досвід виступає верифікацією наших тверджень про Бога, а найкращий спосіб богословити - це доксологія, яка виражається у лі-

${ }^{44}$ Gregorius Palamas, Pro sanctis hesychastis III 2, 24, ed. Meyendorff, vol. 2, c. 685, переклад мій.

${ }^{45}$ Пор. Tănase, , ,Crucifixion” of the Logic, p. 69.

${ }^{46}$ Це спонукало деяких критично налаштованих до Палами дослідників говорити, що Григорій запровадив „радикально нове богослов'я пізнання” та називати його „жорстким прибічником монашого анти-інтелектуалізму”. Пор. G. Podskalsky, Theologie und Philosophie in Byzanz, Byzantinisches Archiv 15, München 1977, 47, 155.

${ }^{47}$ Пор. К. Ware, Tradition and personal experience in later Byzantine theology, „Eastern Churches Review" 3 (1970) 137. 
тургійній прославі всіх діл Господніх, які досвідчуємо через участь. У цьому він також виступає продовжувачем патристичного богословського методу ${ }^{48}$. Таким чином він ,ані не пожертвував Об'явленням заради філософії, ані не обмежився сухим повторенням патристичних позицій, але намагався базувати своє богослов'я на вірі та досвіді Церкви. Таким чином, людина має знання про буття Бога через Його енергії, які Він посилає у світ"49. Антиномія допомагає уникнути творення ,ідола” з Бога, що ризикуємо зробити, якщо намагаємося втиснути Його у наші обмежені, людські концепції та логіку, якій підлягає сотворене буття. Адже проблема богопізнання через філософські спекуляції в тому, що ми творимо Бога на свій образ і подобу, бачачи Бога як певне власне відображення. Натомість Бог є цілковито Іншим, тому може бути пізнаваним, але лише в такий спосіб, в який Він сам Себе об'являє нам, а це можливо лише в досвіді пред-стояння до Нього лицем до лиця, у досвіді зустрічі ${ }^{50}$.

$\mathrm{У}$ цьому й полягає відмінність апофатичного та катафатичного підходу до богослов'я. Катафатичний підхід безпосередньо пов’язаний із „божественними іменами”. Імена Бога - це певні атрибути, які приписуються Богові в процесі нашого богопізнання ${ }^{51}$. Коли людина споглядає сотворений світ, його красу, досконалість, вона вбачає в ньому руку Майстра. Духовний зір людини здатний вловити те, що світ запланований і приведений до буття Богом, і кожна річ має певний принцип, акт волі Бога стосовно неї, який звертає наш погляд до Першопричини. Також Боже провидіння стосовно світу дає нам можливість у катафатичному богослов”і ствердити певні властивості Бога, надати Йому певних характеристик. Оскільки діяльність Бога назовні є нескінченною і всеосяжною, цих імен

48 Див. детальніше P. Miquel, Grégoire Palamas, Docteur de l'Expérience, „Irénikon” 37 (1964) 227-237; A.M. Allchin, The Appeal to Experience in the Triads of St. Gregory Palamas, StPatr 93 (1966) 323-328.

${ }^{49}$ G.I. Mantzaridis, The Deification of Man: St. Gregory Palamas and the Orthodox Tradition, New York 1984, 106, переклад мій.

${ }^{50}$ Пор. К. Ware, The Debate about Palamism, „Eastern Churches Review” 9 (1977) nr 1-2, 4647; Дж.П. Мануссакис, Бог после метафизики: богословская эстетика, пер. Д. Морозовой, Киев 2014, 38 .

${ }^{51}$ Божественні атрибути - це ті характеристики, які випливають із божественних енергій. Діяльність Бога виражає назовні те, чим Бог $є$, і через участь у цих діях, споглядання цих дій, ми пізнаємо ці сутнісні характеристики, або досконалості, які нероздільно і відвічно співіснують із Богом. Що більше, у кожному атрибуті, у кожному своєму вияві Бог існує цілісно і повністю. Енергія $є$ повнотою Бога, а ні в якому разі не „частинкою”. Бог не поділяється в енергіях, розподіляючись серед створінь, а передається кожній істоті в повноті. У кожній 3 енергій Бог цілком споглядається як їхня причина. Пор. Staniloae, The Experience of God, vol. 1, c. 125. Ярослав Пелікан зазначає, що богослов'я є завжди пошуком рівноваги між „виражальним і невиражальним, пізнаваним і непізнаваним”. Пор. Я. Пеликан, Христианская традиџия: история развития вероучения, t. 2: Дух восточного христианства [600-1700], пер. П. Кыржелев, Москва 2007, 30. 
є безмежна кількість, як і божественних думок стосовно речей. 3 іншого боку, діяльність божественної сутності - це випромінення Бога, які виявляють певну характеристику Його сутності, яка сама по собі проста, а тому недоступна до іменування, оскільки іменування - це наслідок поняттєтворчості людського розуму. Будь-яке поняття передбачає, що ми схоплюємо суть об'єкта чи явища й описуємо його, будучи немовби „над” ним та встановлюємо наші правила стосунку або поводження з цим об'єктом. Така об'єктивація Бога не може привести до правдивого пізнання, яке осягається лише тоді, коли ми дозволяємо Іншому дивитися на нас, промовляти, так щоб це знання не було відгомоном нашого власного голосу. Таким чином, найвищою точкою катафатичного богослов'я повинна бути смиренна мовчанка, яка відображає нездатність нашого розуму вийти поза власні рамки ${ }^{52}$.

Саме із цього визнання безсилля людського розуму перед Іншим і починається правдиве богослов'я. К. Уер зазначає: „На перший погляд може здатися, що такий наголос на незбагненності Бога виключає будь-який безпосередній досвід спілкування з Ним. Але насправді багато хто з тих, хто послуговується апофатичним підходом, вбачають у ньому не стільки філософський спосіб означення вищої трансцендентності Бога, скільки (i багато частіше) засіб для злиття із Богом у молитві"53. Григорій Палама зазначає, що негативний підхід, апофатика сама по собі ще не є сходженням до неприступної Трійці, а лише визнанням того, що Вона перевершує імена, які людина їй надає:

„Заперечний шлях доступний першому зустрічному, який тільки цього побажає; він не переображує душу, даруючи йй ангельську гідність; він звільняє розум від творінь, але не може сам по собі дати йому з'єднатися 3 неприступним" 54 .

Але, очевидно, він недостатній, оскільки твердження про те, ким Бог не $є$, ще не відкриває Його суть і не дає жодного знання:

„Одним лише запереченням розум не досягає того, що вище розуму, i саме це сходження $є$ певним розумінням того, що відмінне від Бога, і хоч несе образ цього безвидного споглядання та споглядального сповнення ( $\alpha$ лол $\lambda \lambda \eta \rho \dot{\sigma} \sigma \varepsilon \omega \varsigma)$ розуму, але само таким не $\epsilon^{\prime \prime 5}$.

Справжнє споглядання досягається через відречення від творінь, але не обмежується ним - воно $€$,3’єднанням і обоженням, що таїнственно

${ }^{52}$ Пop. Gregorius Palamas, Pro sanctis hesychastis III 2, 10, ed. Meyendorff, vol. 2, c. 661.

${ }^{53}$ Уер, Православна Церква, с. 70.

${ }^{54}$ Gregorius Palamas, Pro sanctis hesychastis I 3, 21, ed. Meyendorff, vol. 1, c. 153, переклад мій. Григорій Палама відносить катафатичне та апофатичне богослов'я до області природного мислення, пізнання через творіння, адже тут задіяний розум у своєму природному, не переображеному стані.

${ }^{55}$ Пop. ibidem I 3, 19, ed. Meyendorff, vol. 1, c. 149. 
і невимовно здійснюється благодаттю Божою після відречення" ${ }^{\prime 2}$. Йоан Меєндорф наголошує, що цей досвід $€$ позитивним, як позитивним $є$ дар, у якому божество нам відкривається, проте він вищий за відречення - це причастя божественного ${ }^{57}$.

Стан обоження виражається через досвід Таворського світла. Це споглядання не $є$ у властивому значенні діяльністю тілесних чуттів чи людського розуму, навпаки, він можливий тільки тоді, коли природні чуття та розум людини не $є$ задіяні, адже тоді в людині вступає в діяльність сама божественна благодать та перемінює ії зсередини:

„Споглядач, ум якого говорить йому, що він бачить не чуттям як таким, думає, що бачить умом. Але дослідивши і розібравшись, виявляє, що й ум бездіяльний перед світлом. Саме це ми й називаємо «понадрозумовим розумінням», бажаючи сказати, що бачить той, хто має ум та чуття, але бачить вище за них обох. Водночас, почувши пораду великого Діонісія $[\ldots]$ про «полишення чуттів та розумових енергій та порив до істинно Сущого», не роби висновку, ніби людина тоді не може розуміти або бачити - вона не зазнає втрати цих здатностей, хіба що від шоку, але зрозумій, що діяльність розуму залишається безкінечно позаду світла, що єднає та світлоносної енергії's8.

Таким чином божественне світло виявляється трансцендентним відносно людини, яка його споглядає. Для того, щоб його бачити, необхідне переображення усього єства людини, іï духовних чуттів, виходу поза межі власної природи. Це те, що Отці Церкви називали „екстазом”. Однак якщо в Свагрія Понтійського екстаз полягає в тому, щоб ум очистився від будь-яких образів і споглядав Бога у Його простоті ${ }^{59}$, то у Григорія Палами цей стан охоплює всю особу, він $є$ холістичним, адже обожується не лише ум як аспект людини, що найбільш наближений до Бога, а людина в своїй повноті. Ісихасти назиали це світло Божої слави Таворським, адже саме переображення Христа стало найбільш яскравим образом того, що відбувається з людиною, коли вона обожується, як змінюється іiі

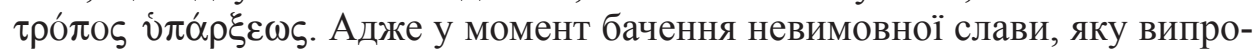
мінював Христос, була можлива тільки завдяки тому, що самі апостоли зазнали переміни. Отже, для того, щоби бачити Бога, людина повинна стати богоподібною, але це завжди виявляється даром Божим, який не залежить від нашого вольового зусилля чи досягнень, а приходить знена-

${ }^{56}$ Пop. ibidem I 3, 17, ed. Meyendorff, vol. 1, c. 145.

${ }^{57}$ Пор. ibidem I 3, 18, ed. Meyendorff, vol. 1, с. 151. Негативна теологія є лише „піднесенням ума до Бога через заперечення" (ibidem II 1, 42, ed. Meyendorff, vol. 1, с. 331). Див. Y. Spiteris, Ostatni Ojcowie Kościoła: Cabasilas, Palamas, thum. B. Widła, Warszawa 2006, 208.

${ }^{58}$ Gregorius Palamas, Pro sanctis hesychastis III 1, 36, ed. Meyendorff, vol. 2, с. 617, переклад мій.

${ }^{59}$ Пор. Шпідлік, Духовність християнського Сходу, с. 269. 


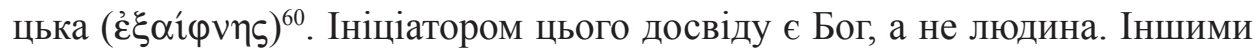
словами, переживаючи цей крайній, „переповнений” досвід Божої присутності, людська особа переживає своєрідний пасивний стан, коли не вона споглядає когось, а радше на неї дивляться, бо якщо б вона користувалася лише своїми природними силами, то вона б ніколи не вийшла за межі висловів „немовби”, „якби”, які виражають нашу нездатність вийти за межі власної, сотвореної парадигми. Але якби ми прагнули обмежити Бога до того, що досяжне для людського розуму, ми ризикуємо „створити Бога на свій образ і подобу" і впасти у небезпечний іманентизм ${ }^{61}$. Тому Григорій Палама говорить, що єднання з Богом не вписується у парадигму людського розуму і навіть противиться йому, оскільки розум в процесі аналізу розщеплює Бога, який перед ним постає, на різні аспекти, а також „виймає себе з Вищого” можливо нічого описати, можливо лише досвідчити це, бо „єднання [...] $\epsilon$ невимовним і немислимим для самих тих, які споглядають. Врешті [...] світло споглядання споглядається іпостасно і невимовно духовно спілкується із тим, кого обожує" ${ }^{\prime 2}$. Таворське світло є вираженням досягнення найглибшого можливого досвіду богоспілкування, яке є передсмаком есхатону і в онтологічному вимірі проявляється у всиновленні Богом:

\begin{abstract}
„Обоження - це видиме воіпостасне осяяння, що не має початку в достойних, а лиш прояв, який неможливо помислити; таїнственне єднання з Богом, що перевершує ум та розум, відбувається в нетлінному віці, коли, споглядаючи світло сокровенне та невимовної слави, разом з вишніми силами святі й самі стають сприймачами блаженної чистоти; і призивання великого Бога й Отця, що служить символом іпостасного та дійсного усиновлення за даром і благодаттю Святого Духа, коли в посіщенні благодаті святі стають синами Божими, якими вони всі й далі будуть" ${ }^{\circ}$.
\end{abstract}

Таким чином ми плавно переходимо до передумов цього досвіду, а саме - того факту, що енергії є іпостасними і служать єднанню між людською особою та Божими Особами. Це радикально відрізняє містицизм ісихастів від неоплатонічного та інших непесоналістичних містицизмів.

3. Особовий вимір богопізнання. Як ми вже побачили, ядром богослов'я Палами є містичний досвід, який він намагається артикулювати,

${ }^{60}$ Так, наприклад, Палама описує досвід первомученика Стефана, коли той говорить: „Ось бачу небо відкрите і Сина Чоловічого, що сидить праворуч Отця”, пор. Gregorius Palamas, Pro sanctis hesychastis I 3, 31, ed. Meyendorff, vol. 1, c. 129.

${ }^{61}$ Пор. А. де Любак, Роздуми про Церкву, пер. С. Желдак, Київ 2010, 183.

${ }^{62}$ Gregorius Palamas, Pro sanctis hesychastis II 3, 35, ed. Meyendorff, vol. 2, c. 449, переклад мій.

${ }^{63}$ Ibidem, переклад мій.

${ }^{64}$ Ibidem III 1, 28, ed. Meyendorff, vol. 2, с. 603, переклад мій. 
пояснити та захистити від раціоналістичних редукцій. Доктрина божественних енергій виступає інтелектуальною основою для справжнього християнського містицизму та є глибоко персоналістичною, оскільки має на меті показати, як Бог об'являє Себе як Особу, як Іншого ${ }^{65}$, щоб отримати вільну та повну захоплення відповідь людини. Тому тут розглянемо обоження завдяки енергіям через призму стосунку любові між Богом і людиною.

Як відомо, саме християнське богослов'я спричинилося до створення поняття особи. До того, як у процесі спорів навколо Трійці Каппадокійські Отці не трансформували значення термінів іпостась і просопон, грецька думка ототожнювала маску, тобто соціальну роль, але не особу в їі унікальності ${ }^{66}$. Проте визначення Каппадокійцями іпостасі як поняття, що виражає загальне в конкретному сущому, але з власними характеристиками, не було достатнім під час христологічних суперечок, тому вже Леонтій Візантійський ха-

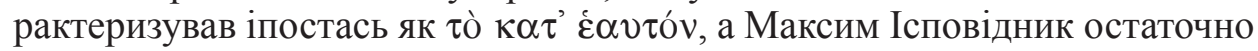

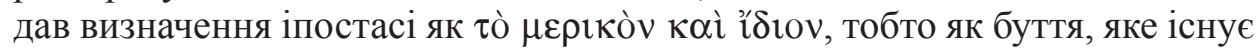
само по собі та володіє своїми власними характеристиками ${ }^{67}$. Слід розрізняти іпостась та індивід: якщо іпостась - це щось, що володіє своїми власними унікальними властивостями, то індивід, або атом, виражає якраз відсутність індивідуальності, присутність загальних характеристик роду і виду в одиничній речі. Крім того, варто уточнити терміни ,іпостась” та „просопон”. Для багатьох Отців Церкви, як, наприклад, Максима Ісповідника, ці поняття $є$ тотожними. Проте Г. Капрієв звертає увагу на те, що іпостась позначає більшою мірою конкретну самовизначеність особи, а просопон має стосунок до взаємодії з іншими, співвідношення 3 іншими особами. Дж. П. Мануссакіс зазначає, що проблема індивідуації, тобто окреслення, чим є та чи інша іпостась, є однією із найскладніших у філософії, адже особу неможливо пояснити через загальні категоpiï, а буття особою означає бути саме цією конкретною особою ${ }^{68}$.

Енергії не мають власної іпостасі, а самі виводяться із іпостасей ${ }^{69}$ та виражають собою божественне існування, тобто дозволяють нам пізнати, що Бог є, незважаючи на те, що Його сутність залишається від нас прихованою. Іпостасність енергій притаманна не лише Богові - енергії людської природи також проявляються через іпостась. Тут важливе зна-

${ }^{65}$ У цій статті ми вживаємо цей термін у тому значенні, якого йому надавали такі філософи-екзистенціалісти та феноменологи, як Ж.-Л. Маріон, М. Гайдеггер, Е. Левінас, а також православні богослови, як-от Дж.П. Мануссакіс, Й. Зізіулас тощо.

${ }^{66}$ Пор. Й. Зізіулас, Буття як спілкування, пер. В. Верлока - М. Козуб, Київ 2005, 27-50.

${ }^{67}$ Пор. Г. Каприев. Ипостась и энергия, у: Современная болгарская патрология, ред. Г. Каприев, Киев 2016, 37.

${ }^{68}$ Пор. Мануссакис, Бог после метафизики, с. 98-99.

${ }^{69}$ Gregorius Palamas, Pro sanctis hesychastis III 1, 18, ed. Meyendorff, vol. 2, c. 593; III 2, 25, ed. Meyendorff, vol. 2, c. 687-689. 
чення має термін „просопон”, який виражає не тільки свободу в вираженні цих енергій назовні, але також фундаментальну властивість особи перебувати у стосунку і в цих відносинах поставати перед іншим. Хоч саме сутність $є$ причиною енергій, вони мають особовий характер ( тасей і спрямовуються Богом в іпостась людини, таким чином обожуючи іiі. Адже єдиносущність не елімінує особовість у Трійці, а є результатом перихорези, койнонії між Особами. Ця перихореза є природною, цілісною, вічною та нероздільною, але не призводить до змішування чи злиття Осіб ${ }^{70}$, до втрати тотожності, так само як Особи не $є$,частинами” Трійці ${ }^{71}$. Як говорить о. Й. Меєндорф, енергії водночас мають особовий характер, але й іманентні до природи Діяча ${ }^{72}$. Важливе значення у цьому

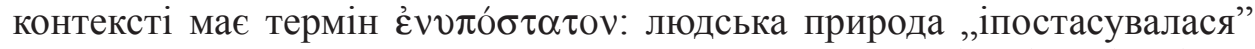
в Особу Сина, Який засвоїв усе, що притаманне людині, крім гріха, і так само благодать обоження може передаватися від божественних Іпостасей до іпостасі людини.

Божественні Іпостасі, на думку Палами, $є$ „вмістилищами” Божого буття, в яких сутність проявляється, а не просто іпостасними відношеннями, що їх можна вирізнити в сутності ${ }^{73}$. Ці властивості-відношення $\epsilon$ радше тим, що характеризує іпостасі ${ }^{74}$, але аж ніяк не творить їх. „Насправді ж Бог існує Сам, і Йому належать і божественна сутність, і божественна енергія"75. Цей уривок показує, що існує першенство Іпостасі перед сутністю, бо і сам Господь каже: „Я Сущий”, а не „Я - Сутність”.

Отож обмін енергіями між Богом та людиною, що має за свій наслідок богопізнання, є нічим іншим, як стосунком любові між Божими Особами та людиною. Дж. П. Мануссакіс характеризує його як просопічні відносини, оскільки просопон - це особа, відкрита до погляду Іншого та спрямована до спільнотного способу існування на зразок Пресвятої Трійці. Буття особою означає стояти перед чиїмось обличчям, бути у його присутності. Термін „просопон” містить у собі екстатичний вимір, бажання вийти поза межі себе та бути „для” та „до” Іншого $^{76}$. Палама характеризує цю співвіднесеність особи як „буття одним духом із Богом". Завдяки іпостасному єднанню Слова Божого 3 людською природою та явлення на Таворі переображеного Христа

\footnotetext{
${ }^{70}$ Пop. idem, Capita physica, theologica, moralia et practica 112, PG 150, 1197B.

${ }^{71}$ Пор. И. Мейендорф, Жизнь и труды свт. Григория Паламы, Санкт-Петербург 1997, 292.

${ }^{72}$ Пор. ibidem, c. 294; H.U. von Balthasar, Cosmic Liturgy: The Universe According to Maximus the Confessor, transl. B.E. Daley, San Francisco 2003, 170-171.

73 До речі, сучасним богословам нерідко закидають, що вони применшують роль сутності як підгрунтя для особи, таким чином зводячи особу до бұє́бเఢ. Послідовну критику цього підходу див. Каприев. Ипостась и энергия, с. 40.

${ }^{74}$ Пор. Мейендорф, Жизнь и труды свт. Григория Паламы, с. 290.

${ }^{75}$ Ibidem, c. 291.

${ }^{76}$ Пор. Мануссакис, Бог после метафизики, с. 60-61.
} 
є можливе єднання людської іпостасі із Трійцею. „Один дух” - це божественна енергія, у якій обожена особа бере участь ${ }^{77}$. Григорій Палама найчастіше описує божественну енергію в пневматологічній термінології:

„Але таке божественне та небесне життя тих, які є достойними учасниками невіддільного життя Духа [...] існує вічно, будучи притаманною за природою Духові, який від віку обожує і якого святі справедливо називають духом і божеством як обожуючий дар, що нітрохи не відділяється від Духа, що його дарує; і воно є світлом, яке відкривається в таїнственному осяянні й відомий лише достойним, іпостасне, але не тому, що у нього власна іпостась, а тому, що Дух посилає це життя «в іпостась іншого», де воно й споглядається. Таким, власне кажучи, є воіпостасне, що споглядається не в собі самому і не в сутності, але в іпостасі"78.

Богослов'я Григорія Палами глибоко вкорінене в персоналізм Східних Отців, які абстрагувалися від сутності, зменшивши їі вагу й наголошували на ролі Іпостасей у богопізнанні. Як зазначає Томас Анастос, цей персоналізм завжди імпліцитно присутній у розрізненні між пізнаваною, доступною енергією та невимовною, таємничою сутністю. Саме іпостасне буття Бога робить схему цього розрізнення цілісною ${ }^{79}$. Вперше ми помічаємо таку тенденцію в Каппадокійців ${ }^{80}$, а Максим Ісповідник ще менше уваги присвячував божественній сутності, натомість зробив іпостась центром будь-якого досвіду спілкування людини й Бога та всякого богослов’я. Те саме характерно і для Григорія Палами. Він проголошує першість особи над сутністю ${ }^{81}$ і говорить, що є різні ,типи буття”, якщо можна їх так назвати: сутність, енергія та особа. Через іпостась Сина на нас сходить благодать обоження, усиновлення, „наяву воіпостасне осяян-

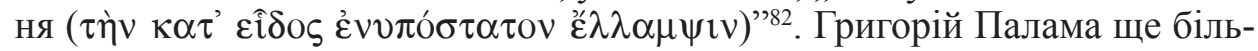
ше ,радикалізував” відношення сутність-іпостась-енергія, аби ствердити можливість онтологічного обоження ${ }^{83}$. Однак термінологічно правильніше говорити не про „сутнісно-іпостасно-енергійне” буття Бога, а Бога як Триособове сутнісно-енергійне буття, щоб це не призвело до розуміння іпостасей як певну середню ланку між сутністю та енергією або відне-

\footnotetext{
${ }^{77}$ Пop. Gregorius Palamas, Capita physica, theologica, moralia et practica 75, PG 150, 1176A.

${ }^{78}$ Idem, Pro sanctis hesychastis III 1, 9, ed. Meyendorff, vol. 2, с. 603, переклад мій.

${ }^{79}$ Пор. T.L. Anastos, Gregory Palamas'Radicalization of the Essence, Energies, and Hypostasis Model of God, GOTR 38 (1993) 340.

${ }^{80}$ Наприклад, Т. Анастос зазначає, що атрибути, такі, як мудрість, благість, велич, силу, вони приписували не божественній сутності, яка „не може бути благою чи мудрою”, а божественним іпостасям, які й виражають ці свої характеристики через само-маніфестацію в енергіях. Див. Anastos, Gregory Palamas' Radicalization of the Essence, p. 341.

${ }^{81}$ Пop. Gregorius Palamas, Pro sanctis hesychastis III 2, 12, ed. Meyendorff, vol. 2, c. 665.

${ }^{82}$ Ibidem III 1, 29, ed. Meyendorff, vol. 2, c. 613.

${ }^{83}$ Пop. Anastos, Gregory Palamas' Radicalization of the Essence, p. 342.
} 
сення їх до непізнаваної сутності. Радше іпостасі є трансцендентними у сутності та об'являються, стають іманентними через енергії ${ }^{84}$

У цій статті ми розглянули, яким чином Григорій Палама артикулює містичний досвід монахів-ісихастів за допомогою свого вчення про розрізнення між сутністю та божественними енергіями. Вчення Григорія Палами має під собою великий пласт досліджень попередників, які також намагались вивести певні закономірності та передумови богопізнання. Це Каппадокійські Отці, Псевдо-Діонісій Ареопагіт, Максим Ісповідник, Йоан Дамаскин (чий вплив на Паламу ми не заторкували) та інші. Григорій Палама говорить про реальне розрізнення між сутністю та енергіями

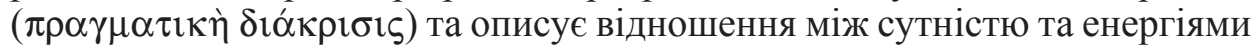
за допомогою термінології неоплатонізму - сопричасне, несопричасне, учасники (втім, як ми побачили, за цими термінами стоять зовсім інші речі, аніж в неоплатонізмі). Також він наголошує на необхідності, щоб ці енергії були нетварними, адже в іншому випадку вони ніяк не зможуть об'являти Бога й обожувати людину. Саме досвід обоження є для Григорія Палами засновком для всіх наступних умовиводів.

У своїй теорії пізнання Григорій наголошує на важливості містичного досвіду, який він вважає джерелом знання, яке найбільше гідне довіри. Палама дотримується патристичної методології богопізнання, тобто вважає, що тільки особистий досвід зустрічі з Богом або спілкування з людьми, які мали такий досвід, відкриває нам правдиве знання Бога, натомість знання, почерпнуте з розуму, є фрагментарним, неповним та таким, що об'єктифікує Бога й робить з Нього предмет наукового розгляду замість живого спілкування з Ним. Щоб підкреслити це, Палама говорить про антиномічність буття Бога, яке не надається до раціоналізацій. Справжнє пізнання Бога через енергії відбувається через екстаз - трансценденцію понад людські можливості, коли обожена людина дозволяє Богові себе вознести й переобразити.

Паламів підхід до богослов'я був би неповним і непослідовним, якби в ньому не підкреслювалося, що стосунок між Богом і людиною, а отже, й енергії, є особовими, воіпостасними. Це тісно пов'язано з тайною Воплочення та троїчного буття Бога. Обмін енергіями між Божою та людською іпостасями проявляється у стосунках любові та полишенні будьякого чуттєвого та розумового сприйняття позаду на час цього досвіду. Таким чином, людина визнає, що справжнє богопізнання завжди перевершує іiі власну природу.

${ }^{84}$ Пop. J. Meyendorff - M. Fahey, Trinitarian Theology East and West: Aquinas and Palamas, Brookline 1977, 37. 


\section{DIVINE ENERGIES AND THEOLOGICAL METHOD IN ST. GREGORY PALAMAS}

(Summary)

Gregory Palamas' theory of divine uncreated energies is closely connected with his defence of Hesychastic prayer and mysticism of the Tabor light. His first and immediate goal was to articulate the possibility of theosis and participation in divine life and glory as well as the chance for a man to become God-like, though not in his essence, but by God's grace. Mysticism and doxology, communion with God is for Palamas the only adequate context of God's self-manifestation and man's reception of this self-presenting. This article is aiming at presenting some glimpses at the personalist and existential aspects of St. Gregory Palamas' theology on the essence-energies distinction and Hesychast experience of the uncreated light.

\section{BOSKIE ENERGIE I METODA TEOLOGICZNA W NAUCZANIU ŚW. GRZEGORZA PALAMASA}

\section{(Streszczenie)}

Teoria Grzegorza Palamasa o niestworzonych energiach Boskich jest ściśle związana z jego obroną modlitwy hezychastycznej i mistyki światła Taborskiego. Jego pierwszym i głównym celem było to, aby wyartykułować możliwość przebóstwienia człowieka i jego uczestnictwa w życiu i chwale Boga, a także szansę upodobnienia do Boga - nie w Jego istocie, ale przez Jego łaskę. Mistycyzm i doksologia, wspólnota z Bogiem jest dla Palamasa wyjątkowo odpowiednim kontekstem dla Boskiego samo-objawienia jak również recepcji Bożego zjawiska przez człowieka. Niniejszy artykuł ma na celu przedstawienie niektórych elementów wymiaru personalistycznego i egzystencjalnego teologii św. Grzegorza Palamasa $\mathrm{w}$ aspekcie rozróżnienia między istotą a energiami w Bogu, jak również w aspekcie hezychastycznego doświadczenia niestworzonego światła.

Key words: essence-energies distinction, knowledge of God, antinomy, mysticism, Tabor light, uncreated energies, experience, enupostaton.

Słowa kluczowe: rozróżnienie między istotą a energiami, poznanie Boga, antynomia, mistycyzm, światło Taborskie, niestworzone energie, doświadczenie, enupostaton.

Ключові слова: розрізнення між сутністю та енергіями, богопізнання, антиномія, містицизм, Таворське світло, нетварні енергії, досвід, воіпостасне. 


\title{
БІБЛІОГРАФІЯ
}

\author{
Джерела
}

Athanasius Alexandrinus, Epistulae ad Serapionem, PG 26, 525-681.

Dionysius Areopagita, De divinis nominibus, PG 3, 586-997.

Gregorius Nazianzenus, Orationes 27-31, éd. P. Gallay - M. Jourjon, SCh 250, Paris 1978.

Gregorius Palamas, Capita physica, theologica, moralia et practica, PG 150, 1121-1225.

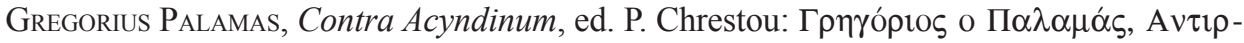

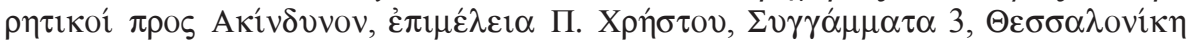
1970.

Gregorius Palamas, Pro sanctis hesychastis, ed. J. Meyendorff: Grégoire Palamas, Défense des saints hésychastes, introduction, texte critique, traduction et notes par J. Meyendorff, vol. 1-2, Spicilegium Sacrum Lovaniense 30-31, Louvain 1959

Maximus Confessor, Opuscula theologica et polemica ad Marinum, PG 90, 9-286.

Proclus, Institutio theologia, ed. and transl. by E.R. Dodds: Proclus, The Elements of Theology, A Revised Text with Translation, Introduction, and Commentary by E.R. Dodds, Oxford 1933.

\section{Література}

Allchin A.M., The Appeal to Experience in the Triads of St. Gregory Palamas, StPatr 93 (1966) 323-328.

Anastos T.L., Gregory Palamas'Radicalization of the Essence, Energies, and Hypostasis Model of God, GOTR 38 (1993) 335-349.

Balthasar H.U. von, Cosmic Liturgy: The Universe According to Maximus the Confessor, transl. B.E. Daley, San Francisco 2003.

Bradshaw D., Aristotle East and West: Metaphysics and the Division of Christendom, New York 2004.

Cheng J., The Distinction between God's Essence and Energy: Gregory Palamas' Idea of Ultimate Reality and Meaning, „Ultimate Reality and Meaning: Interdisciplinary Studies in Philosophy of Understanding" 21 (1998) 109-117.

Conticello C.G. ET V., La théologie byzantine et sa tradition, vol. 2, Turnhout 2002.

Contos L.C., The Essence-Energies Structure of St Gregory Palamas with a Brief Examination of Its Patristic Foundation, GOTR 12 (1967) 283-294.

Krivosheine V., The Ascetic and Theological Teaching of Gregory Palamas, „Eastern Church Review" 3 (1938) 26-33, 71-84, 138-156 та 193-214.

Lossky V., In the Image and Likeness of God, transl. J.H. Ericson - T.E. Bird, New York 1974. Louth A., The Origins of Christian Mystical Tradition: from Plato to Denys, New York 2007. Louth A., Reception of Dionysius in the Byzantine world: Maximus to Palamas, „Modern Theology" 24 (2008) 585-599.

Mantzaridis G.I., The Deification of Man: St. Gregory Palamas and the Orthodox Tradition, New York 1984.

Meyendorff J. - Fahey M., Trinitarian Theology East and West: Aquinas and Palamas, Brookline 1977.

Miquel P., Grégoire Palamas, Docteur de l’Expérience, „Irénikon” 37 (1964) 227-237.

Papanikolaou A., Being with God: Trinity, Apophaticism, and Divine-Human Communion, Notre Dame 2006. 
Podskalsky G., Theologie und Philosophie in Byzanz, Byzantinisches Archiv 15, München 1977.

ReID D., Energies of the Spirit. Trinitarian Models in Eastern Orthodox and Western Theology, Atlanta 1997.

Spiteris Y., Ostatni Ojcowie Kościoła: Kabasilas, Palamas, thum. B. Widła, Warszawa 2006.

Staniloae D., The Experience of God: Orthodox Dogmatic Theology, vol. 1: Revelation and Knowledge of the Triune God, transl. I. Ionita - R. Barringer, Brookline 1998.

StĂNILOAe D., Viața şi Învățătura Sfântului Grigorie Palama, Bucureşti 1993.

Tănase N., ,Crucifixion” of the Logic. Palamite Theology of the Uncreaded Divine Energies as Fundament of an Ontological Epistemology, ,International Journal of Orthodox Theology" 6 (2015) nr 4, 69-106.

TANEv S., ENEPГЕIA vs ГOФIA: The Contribution of Fr. Georges Florovsky to the Rediscovery of the Orthodox Teaching on the Distinction between the Divine Essence and Energies, „International Journal of Orthodox Theology” 2 (2011) nr 1, 15-71.

WARE K., God Hidden and Revealed: The Apophatic Way and the Essence-Energies Distinction, „Eastern Churches Review” 7 (1975) 130-131.

WARE K., The Debate about Palamism, „Eastern Churches Review” 9 (1977) nr 1-2, 45-63.

WARE K., The Inner Unity of the Philokalia and its Influence in East and West, Athens 2004.

WARE K., Tradition and personal experience in later Byzantine theology, „Eastern Churches Review" 3 (1970) 131-141.

YANNARAs C., The Distinction between Essence and Energies and Its Importance for Theology, VTQ 19 (1975) 232-245.

Жуковський В., Святий Григорій Палама і його легітимізація в УГКЦ, „Наукові записки УКУ. Серія «Богослов'я»" 1 (2009) 145-159.

ЗІзгулАс Й., Буття як спілкування, пер. В. Верлока - М. Козуб, Київ 2005.

КАПРИЕВ Г., Ипостась и энергия, у: Современная болгарская патрология, ред. Г. Каприев, Киев 2016.

Керн К., Антропология св. Григория Паламы, Москва 1996.

Лосский В., Очерк мистического богословия Восточной Церкви. Догматическое богословие, Москва 1991.

ЛюБАК А. ДЕ, Роздуми про Церкву, пер. С. Желдак, Київ 2010.

МАНУССАКИс Дж.П., Бог после метафизики: богословская эстетика, пер. Д. Морозовой, Киев 2014.

МЕйЕндоРФ И., Жизнь и труды свт. Григория Паламь, Санкт-Петербург 1997.

ПЕликАН Я., Христианская традиция: история развития вероучения, t. 2: Дух восточного христианства [600-1700], пер. П. Кыржелев, Москва 2007.

Пентковский А.М., От „Искателя непрестанной молитвы” до „,Откровенных рассказов странника”: (К вопросу об истории текста), „Символ” 27 (1992) 137-166.

Уер К., Православна Церква, пер. Н. Рогачевської, Київ 2009.

Флоровский Г., Святой Григорий Палама и традиция Отияов, пер. Н. Холмогоровой, „Альфа и Омега” 9/10 (1996) 107-116.

Хоружий С., Общение и созецание, исихазм и неоплатонизм: к взаимосвязи проблем, у: Общение-Соттипіо-Коіпопіа: истоки, пути осмьсления и воплощения. Успенские чтения, Киев 2015.

Шпцдлік Т., Духовність християнського Сходу, пер. з італ. Мар'яна Прокопович, Львів 1999. 